\title{
Association of infant alimentary and respiratory illness with parental smoking and other environmental factors
}

\author{
S A OGSTON, ${ }^{1}$ C DU V FLOREY, ${ }^{1}$ AND C H M WALKER ${ }^{2}$ \\ From the Department of Community Medicine, ${ }^{1}$ and the Department of Child Health, ${ }^{2}$ Ninewells Hospital and \\ Medical School, Dundee DDI 9SY
}

SUMMARY The incidences of alimentary and respiratory illnesses were observed during the first year of life in 1565 infants born in Tayside during 1980. Significant correlations $(p<0.05)$ were found between each of these outcomes and parental smoking, maternal age, social class, method of infant feeding, and heating fuels. Multiple logistic regression indicated a significant independent effect of parental smoking was related separately to alimentary and to respiratory outcomes, the relative risks being of similar strength.

Said and co-workers ${ }^{1}$ were the first to report an association between parental smoking and postprandial colic and other digestive symptoms in infants. In their study of 253 3-month-old infants, mothers were asked at a routine consultation whether the child cried after feeding and seemed to be in pain. There appeared to be a dose-response relation between parental smoking and reported post-prandial colic, rising from an incidence of $34 \%$ in children with non-smoking parents to $90 \%$ in children where both parents smoked. Children with one parent who smoked had an intermediate incidence.

This report led us to examine the reported alimentary illness among infants born in Tayside. We examined disease incidence during the first year of life in relation to several potential risk factors including parental smoking.

\section{Subjects and methods}

The data were gathered as part of the Tayside Infant Morbidity and Mortality Study. ${ }^{2}$ The subjects were the infants of primigravidae who had made an initial booking at any of the Tayside antenatal clinics during 1980. Health visitors interviewed the parents to obtain their ages, social class, ethnic groups, and various aspects of their housing and accommodation including the main methods of cooking and heating. Information on the father's smoking habits and on the mother's smoking habits during pregnancy was obtained at the first antenatal interview. Further information on her smoking during pregnancy was obtained from a postnatal questionnaire completed by the mother while in hospital. As these data were provided by only $80 \%$ of the mothers and there was good agreement between the antenatal and postnatal responses, we classified smoking according to the former source. Current data (unpublished) for Tayside mothers indicate that although during pregnancy smokers reduce the number of cigarettes smoked, few abstain. Among families with smokers we found no trend of increasing infant morbidity with number of cigarettes smoked daily. In the light of these observations we categorised the parents according to whether or not they smoked, categories which could be expected to remain valid during and after pregnancy. A summary record was completed when the child was 1 year of age and included a report on the child's illnesses during the first year of life derived from observations made by the health visitors during their scheduled visits to see the child. A paediatrician verified the diagnostic criteria and consistency.

Disease incidence was defined here as the presence of at least one episode of illness recorded by the health visitor. An episode of respiratory illness was defined as infection of the upper or lower respiratory tract. Alimentary illnesses were mainly diarrhoea or vomiting, or colic. The separate medical conditions were not recorded for the collective diagnoses of respiratory and alimentary illness.

The statistical methods used included chi squared for contingency tables, with partitioning and for trend. Multiple logistic regression and log-linear models were fitted using the computer package GLIM. ${ }^{3}$

\section{Results}

A total of 1940 mothers were interviewed, representing over $95 \%$ of the mothers of first singleton children who booked at the antenatal clinics. Thirty of the 
children died-11 stillbirths and 19 infant deathsleaving 1910 on whom data from the initial interview were available. This figure was reduced to $1565(82 \%)$ infants on whom data for a whole year were recorded, because some families left the region and some health visitors did not return the one-year follow-up information. One or more episodes of alimentary illness were observed in 271 infants $(17 \cdot 3 \%)$ and respiratory illness in 494 (31.6\%).

Initial tabulation of the data resulted in father's age, cooking type, number of people living in the household, and whether the mother was working during pregnancy being discarded as either not important or containing information implicit in retained variables. The absence of a significant relation between respiratory illness and cooking fuel in this data set has been described in detail elsewhere. ${ }^{4}$ Table 1 shows the incidence rates for alimentary and respiratory illnesses according to the main risk factors

Table 1 Incidence rates (\%) of reported alimentary and respiratory diseases in the first year of life according to five risk factors

\begin{tabular}{|c|c|c|c|}
\hline Risk factor & No. & $\begin{array}{l}\text { Alimentary } \\
\text { illness }(\%)\end{array}$ & $\begin{array}{l}\text { Respiratory } \\
\text { illness }(\%)\end{array}$ \\
\hline $\begin{array}{l}\text { Parents smoking } \\
\text { Neither } \\
\text { Father only } \\
\text { Mother only } \\
\text { Both } \\
\text { Not known }\end{array}$ & $\begin{array}{r}588 \\
338 \\
177 \\
439 \\
23\end{array}$ & $\begin{array}{l}14 \cdot 5 \\
14 \cdot 5 \\
19 \cdot 2 \\
22 \cdot 8 \\
13 \cdot 0\end{array}$ & $\begin{array}{l}24 \cdot 8 \\
33 \cdot 1 \\
38 \cdot 4 \\
36 \cdot 4 \\
34 \cdot 8\end{array}$ \\
\hline p (chi-square; 3df) & & $<0.01$ & $<0.001$ \\
\hline $\begin{array}{l}\text { Maternal age (yr) } \\
15- \\
20- \\
30-\end{array}$ & $\begin{array}{r}334 \\
1088 \\
143\end{array}$ & $\begin{array}{l}22 \cdot 5 \\
16 \cdot 6 \\
10 \cdot 5\end{array}$ & $\begin{array}{l}37 \cdot 7 \\
30 \cdot 1 \\
28 \cdot 7\end{array}$ \\
\hline p (chi-square; Idf) & & $<0.01$ & $<0.05$ \\
\hline $\begin{array}{l}\text { Feeding } \\
\text { Breast } \\
\text { Bottle } \\
\text { Not known }\end{array}$ & $\begin{array}{r}757 \\
769 \\
39\end{array}$ & $\begin{array}{r}15 \cdot 2 \\
19 \cdot 9 \\
7 \cdot 7\end{array}$ & $\begin{array}{l}29 \cdot 2 \\
34 \cdot 5 \\
20 \cdot 5\end{array}$ \\
\hline p (chi-square; ldf) & & $<0.05$ & $<0.05$ \\
\hline $\begin{array}{l}\text { Heating type } \\
\text { Central } \\
\text { Storage } \\
\text { Coal } \\
\text { Gas } \\
\text { Electric } \\
\text { Others }\end{array}$ & $\begin{array}{r}431 \\
170 \\
215 \\
177 \\
543 \\
29\end{array}$ & $\begin{array}{l}17 \cdot 4 \\
11 \cdot 8 \\
15 \cdot 3 \\
14 \cdot 1 \\
20 \cdot 4 \\
24 \cdot 1\end{array}$ & $\begin{array}{l}28.8 \\
25.9 \\
27.4 \\
37.9 \\
35 \cdot 0 \\
34.5\end{array}$ \\
\hline p (chi-square; 5df) & & $<0.10$ & $<0.05$ \\
\hline $\begin{array}{l}\text { Father's social class } \\
\text { I } \\
\text { II } \\
\text { IIIn } \\
\text { IIIm } \\
\text { IV } \\
\text { V } \\
\text { Not known }\end{array}$ & $\begin{array}{r}121 \\
239 \\
106 \\
628 \\
236 \\
142 \\
93\end{array}$ & $\begin{array}{l}13 \cdot 2 \\
11 \cdot 3 \\
18 \cdot 9 \\
16 \cdot 1 \\
18 \cdot 6 \\
26 \cdot 1 \\
28 \cdot 0\end{array}$ & $\begin{array}{l}28 \cdot 9 \\
25 \cdot 1 \\
27 \cdot 4 \\
33 \cdot 1 \\
34 \cdot 7 \\
32 \cdot 4 \\
36 \cdot 5\end{array}$ \\
\hline $\begin{array}{l}\text { p (chi-square for trend; } 1 \mathrm{df} \text { ) } \\
\text { p (chi-square: manual } v \\
\qquad \text { non-manual; Idf) }\end{array}$ & & $\begin{array}{l}<0.001 \\
<0.05\end{array}$ & $\begin{array}{l}<0.05 \\
<0.01\end{array}$ \\
\hline
\end{tabular}

Not known categories excluded from $\chi^{2}$ calculation of parental smoking, maternal age, bottle feeding, type of heating, and social class. There were missing data for parental smoking, feeding, and father's social class, as indicated.

Among families with smokers there was no trend of increasing infant morbidity with number of cigarettes smoked daily. The parents were therefore classified simply as smokers or non-smokers. Alimentary illness suggested an association mainly with mother's smoking habit, whereas respiratory illness was associated with smoking by either parent. Incidence rates for both alimentary and respiratory illness were consistent with a trend of increasing incidence from families in which neither parent smoked, through those in which the father smoked, to those in which the mother or both parents smoked ( $\chi^{2}$ for trend analysis).

Both alimentary and respiratory illness showed a trend of declining incidence with increasing age of mother, and there was evidence of lower incidence among the breast fed than the bottle fed infants.

The categories of heating type given in table 1 correspond to the main type of heating used in the household. There were significant differences between heating types for respiratory illness only. Alimentary illness was strongly and positively related to social class whereas respiratory illness showed significantle higher rates among manual compared with nono manual groups. Both trends were consistent with social class gradient; neither showed significant deviation from a linear trend.

\section{MULTIPLE REGRESSION}

Because the risk factors were correlated with each other, we analysed their combined influence using multiple regression. For this investigation, in order to reduce the overall number of categories, those individuals with 'not known' or 'other' responses on any variable (social class, heating, father's smoking, feeding) were excluded from the analysis. In addition, social class was recoded simply as non-manual (I, II, IIInm) or manual (IIIm-V). The total number of cases was thereby reduced to 1401 .

The incidence of alimentary illness was calculated for each of the cells in the contingency table defined by combination of parental smoking (4 levels), maternal age (3 levels), social class ( 2 levels), feeding ( 2 levels),

and heating ( 5 levels).
Of the single factors, parental smoking and maternal age were the most significant (table 2). All the possible two-factor models were fitted, the results of two of which are shown. Stepwise inclusion of the 9 factors suggested that parental smoking and age and $N$ possibly heating type gave a satisfactory description of N the data. Including extra factors in the model or two factor interaction terms did not give further significant improvement in fit. 
Association of infant alimentary and respiratory illness with parental smoking and other environmental factors 23

Table 2 Analysis of deviance (approximately distributed as chi-square) for multiple logistic regression models

\begin{tabular}{|c|c|c|c|}
\hline $\begin{array}{l}\text { Factors } \\
\text { fitted }\end{array}$ & $d f$ & $\begin{array}{l}\text { Alimentary } \\
\text { illness } \\
G^{2}\end{array}$ & $\begin{array}{l}\text { Respiratory } \\
\text { illness } \\
G^{2}\end{array}$ \\
\hline None & 173 & $215 \cdot 2$ & $228 \cdot 2$ \\
\hline \multicolumn{4}{|l|}{ Single factor models } \\
\hline $\begin{array}{l}\text { Parental smoking (PS) } \\
\text { Maternal age (MA) } \\
\text { Social class (SC) } \\
\text { Feeding (FE) } \\
\text { Heating (HE) }\end{array}$ & $\begin{array}{l}170 \\
171 \\
172 \\
172 \\
169\end{array}$ & $\begin{array}{l}205 \cdot 9^{*} \\
206 \cdot 4^{*} \\
210 \cdot 4^{*} \\
211 \cdot 9+ \\
207 \cdot 1+\end{array}$ & $\begin{array}{l}208 \cdot 9^{* * *} \\
223 \cdot 3+ \\
227 \cdot 7^{*} \\
223 \cdot 4^{*} \\
211 \cdot 9^{* *}\end{array}$ \\
\hline \multicolumn{4}{|l|}{ Two-factor models } \\
\hline $\begin{array}{l}\text { PS + HE } \\
\text { PS + MA }\end{array}$ & $\begin{array}{l}166 \\
168\end{array}$ & $\begin{array}{l}198 \cdot 9- \\
200 \cdot 2+\end{array}$ & $\begin{array}{l}195 \cdot 8 * \\
206 \cdot 5-\end{array}$ \\
\hline \multicolumn{4}{|l|}{ Three-factor models } \\
\hline $\mathbf{P S}+\mathbf{M A}+\mathbf{H E}$ & 164 & 193.0 & $193 \cdot 1$ \\
\hline
\end{tabular}

$-\mathrm{NS}+\mathrm{p}<0.10 * \mathrm{p}<0.05 *{ }^{* *}<0.01 * * * \mathrm{p}<0.001$

174 of the 240 possible cells defined by combinations of the six risk factors actually contained observations. Significance levels are given for single factor models calculated using chi-square test for reduction in $\mathbf{G}^{2}$ compared with the null model; for 2 -factor models $\mathbf{G}^{\mathbf{2}}$ was compared with that for parental smoking.

For alimentary illness, PS + MA + HE is significant compared with (PS + HE)

The overall goodness of fit test $\left(G^{2}=193.0\right.$ on 164 df) does not indicate a very good fit $(p=0 \cdot 06)$. This may be due partly to the large number of cells in the table with small denominators. Thirty-seven of the 174 cells had a denominator of one, and 23 a denominator of two.

The estimated parameters in the regression equation of the log-odds of incidence on parental smoking, type or heating, and maternal age show the positive association with mother's smoking and negative association with age (table 3 ). The results are in qualitative agreement with the analysis of the crude rates given in table 1 . While the families with only fathers who smoked apparently have a similar incidence to non-smoking families, the results are consistent within the limits of sampling variation, with mothers smoking being the main effect and father's smoking habit having a smaller influence. Storage heating, gas and coal fired homes were associated with lower incidences of alimentary symptoms, though the significance levels of these coefficients are low.

A parallel analysis was carried out using respiratory illness in the first year as the outcome variable (table 2). The results of this analysis including other factors have been published elsewhere. ${ }^{4}$

In the analysis of respiratory illness, parental smoking was the most significant factor, while heating type was also significant. None of the remaining factors gave further significant information when included in the analysis, though for comparison with the results obtained for alimentary illness, the equation with parental smoking, age, and heating type was also fitted.
Table 3 Regression coefficients (with standard errors) in multiple logistic analysis of alimentary and respiratory illness

\begin{tabular}{|c|c|c|c|}
\hline \multirow[b]{2}{*}{ Term } & & \multicolumn{2}{|c|}{ Outcome variables } \\
\hline & & $\begin{array}{l}\text { Alimentary } \\
\text { illness }\end{array}$ & $\begin{array}{l}\text { Respiratory } \\
\text { illness }\end{array}$ \\
\hline General mean & & $-1.37 \quad(0.21)$ & $-0.94 \quad(0.19)$ \\
\hline $\begin{array}{l}\text { Parental smoking } \\
\text { Neither } \\
\text { Father } \\
\text { Mother } \\
\text { Both }\end{array}$ & & $\begin{array}{l}0 \\
0.00(0 \cdot 20) \\
0.20(0 \cdot 24) \\
0.38(0 \cdot 18)\end{array}$ & $\begin{array}{c}0 \\
0.36(0 \cdot 16) \\
0.60(0 \cdot 19) \\
0.43(0 \cdot 15)\end{array}$ \\
\hline $\begin{array}{l}\text { Heating } \\
\text { Central } \\
\text { Storage } \\
\text { Coal } \\
\text { Gas } \\
\text { Electric }\end{array}$ & & $\begin{array}{l}0 \\
-0.49(0.29) \\
-0.23(0.24) \\
-0.43(0.27) \\
0.04(0.18)\end{array}$ & 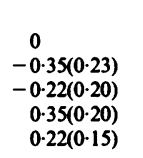 \\
\hline Maternal age (yr) & $\begin{array}{r}<20 \\
20- \\
30\end{array}$ & $\begin{array}{l}0 \\
-0.28(0.18) \\
-0.76(0.33)\end{array}$ & $\begin{array}{l}-0.24(0.15) \\
-0.13(0.24)\end{array}$ \\
\hline
\end{tabular}

The presence of maternal smoking and, to a lesser extent, heating type as explanatory variables in both respiratory and alimentary illness suggested that it might be possible to fit an equation describing the dependence of both outcome variables on the risk factors simultaneously. Furthermore, one might test for both outcomes on these common risk factors to determine whether the same children tended to experience both types of morbidity.

We can distinguish between (i) where parental smoking has an effect on both alimentary and respiratory diseases, and (ii) where, in addition, the incidences of alimentary and respiratory illnesses are positively correlated. In other words, we can determine whether the risk of respiratory illness is greater if the child suffers from alimentary disease. This may be the case, for example, if there are other shared but unmeasured risk factors present.

It is also desirable to assess whether the observed associations of parental smoking and heating type are consistent between the two outcome variables.

The situation may be modelled according to a method used by Goldstein ${ }^{5}$ in analysing longitudinal studies. A five-way contingency table is formed from the two binary outcome factors of respiratory and alimentary illness and the three explanatory (or 'risk') factors identified earlier: parental smoking, maternal age (recorded as $<25$ years and $25+$ years), and heating type.

This contingency table may be modelled using log-linear models. ${ }^{6}$ In the simple situation of a single outcome, interest lies in the interaction terms between this factor and the other explanatory factors. These terms and their standard errors may be estimated by maximum likelihood and their significance tested by omitting them from the model and assessing the 
change in goodness of fit statistics. With a binary outcome factor the results obtained are equivalent to the results of a logistic regression of outcome on the explanatory factors.

The log-linear approach can be extended to two outcome factors by defining a contingency table in the same way. First order interactions between each outcome factor and the explanatory factors have similar interpretation to the single outcome model. The interaction term between the two outcome factors measures the tendency of the two outcomes to occur together. Higher order interactions between the two outcome factors and the rest reflect a possible modification of this association by the explanatory variables.

In GLIM, we represent the observed frequencies by a vector and define GLIM 'factors' $Y 1, Y 2, X 1, X 2$, $\mathrm{X} 3$ to label the categories of the two outcome and three explanatory variables. Level 1 of Y1 and Y2 denotes absence of the disease, level 2 its presence. For the risk factors, similarly, level 1 denotes the baseline (lowest risk) level, determined from the earlier results. We then fit the following sequence of models:

(1) X1, X2, X3 and all their interactions, with Y1 and $Y 2$ main effects.

(2) Model 1 plus Y1.Y2-allowing for association of the two outcome variables.

(3a) Model 2 plus Y1.X1, Y1.X2, Y1.X3, to represent the main effects of the $X$ factors on Y1.

(3b) Model 3a plus Y2.X1, Y2.X2, Y2.X3, to represent the main effects of the $X$ factors on Y2

(4) Model 3b plus Y1.Y2.X1, Y1.Y2.X2, and Y1.Y2.X3 which denote possible modification of the association between $Y 1$ and $Y 2$ in the presence of $X 1$, $\mathrm{X} 2$, and $\mathrm{X} 3$ risk factors.

The results of this modelling process showed that the data were consistent with the simpler model $3 \mathrm{~b}$ without including the outcome interaction terms (table 4). Omitting the RESP.ALIM term from model $3 \mathrm{~b}$ gave an increase in deviance of only $0.80(1 \mathrm{df})$. The original approach of modelling alimentary and respiratory outcomes separately was therefore a

Table 4 Analysis of deviance for combined log-linear model

\begin{tabular}{|c|c|c|c|c|}
\hline \multicolumn{3}{|c|}{ Factors fitted } & $G^{2}$ & $d f$ \\
\hline $\begin{array}{l}\text { (1) } \\
\text { (2) } \\
\text { (3a) } \\
(3 b) \\
(4)\end{array}$ & $\begin{array}{l}\text { PS + MA + HE + intera } \\
\text { + RESP + ALIM } \\
\text { + RESP.ALIM } \\
\text { + RESP.PS + RESP.M } \\
\text { + ALIM.PS + ALIM.1 } \\
\text { + RESP.ALIM. (PS + }\end{array}$ & $\begin{array}{l}\text { ctions } \\
\text { A + RESP.HE } \\
\text { AA + ALIM.HE } \\
\text { MA + HE) }\end{array}$ & $\begin{array}{r}152 \cdot 2 \\
151 \cdot 9 \\
118 \cdot 2 \\
100 \cdot 2 \\
93 \cdot 6\end{array}$ & $\begin{array}{r}118 \\
117 \\
109 \\
101 \\
93\end{array}$ \\
\hline Mod & $\begin{array}{r}\text { del } 3 b \text { with constraints } \\
\text { and }\end{array}$ & $\begin{array}{l}\text { ALIM.MA }=\mathbf{R} \\
\text { ALIM.PS }=\mathbf{R E}\end{array}$ & $A_{103.4}$ & 105 \\
\hline
\end{tabular}

$S$ A Ogston, C du V Florey, and C H M Walker

justified alternative, and the coefficients representing the effects of the risk factors on the two outcomes in the combined analysis (table 5) agreed closely with those from the separate regressions (table 3 ).

An advantage of using the combined model is that we can also test the consistency of the regression coefficients of Y1 and Y2 on one of the explanatory factors, eg, X1. In GLIM, the same analysis as outlined above may be obtained with $\mathrm{Y} 1$ and $\mathrm{Y} 2$ declared as $(0,1)$ variates instead of two-level factors. If we then compute a new variate $\mathrm{YS}=\mathrm{Y} 1+\mathrm{Y} 2$ and fit model 3 with the $Y 1 . X 1$ and $Y 2 . X 1$ terms replaced by YS.X1 we effectively fit model $3 b$ with the Y1.X1 and Y2.X1 interaction terms held equal. Imposing the constraints ALIM.PS = RESP.PS and ALIM.MA = RESP.MA did not increase the deviance significantly $\left(G^{2}=103,4 ; \mathrm{df}=105\right)$, suggesting that the effects of PS and MA were consistent between the two outcomes. The resulting coefficients give the logistic regression coefficients on either outcome as:

$\begin{array}{lr}\text { Only father smoking } & 0 \cdot 24(0 \cdot 13) \\ \text { Only mother smoking } & 0 \cdot 47(0 \cdot 15) \\ \text { Both parents smoking } & 0 \cdot 46(0 \cdot 11) \\ \text { Mothers aged }>25 \text { years } & -0 \cdot 14(0 \cdot 10)\end{array}$

Imposing the further constraint that ALIM.HE = RESP.HE increases the deviance to $\mathrm{G}^{2}=109 \cdot 2 ; \mathrm{df}=109$. This indicates that the differences between the effects of heating type on the two outcomes might be attributable to sampling variation However, most of the increase in $G^{2}$ appeared to arise from differences between the effects of gas heating on respiratory and on alimentary outcomes.

\section{Discussion}

The general finding in our data was that parental smoking was associated with higher reported alimentary and respiratory illness in the first year of

Table 5 Estimated coefficients in log-linear analysis of alimentary and respiratory illness

\begin{tabular}{|c|c|c|}
\hline Term & $\begin{array}{l}\text { Alimentary } \\
\text { illness }\end{array}$ & $\begin{array}{l}\text { Respiratory } \\
\text { illness }\end{array}$ \\
\hline $\begin{array}{l}\text { Parental smoking } \\
\text { Neither } \\
\text { Father only } \\
\text { Mother only } \\
\text { Both }\end{array}$ & $\begin{array}{l}0 \\
0.03(0.21) \\
0.25(0.24) \\
0.45(0.18)\end{array}$ & $\begin{array}{l}0 \\
0.37(0 \cdot 16) \\
0.61(0 \cdot 19) \\
0.45(0 \cdot 15)\end{array}$ \\
\hline $\begin{array}{l}\text { Heating } \\
\text { Central } \\
\text { Storage } \\
\text { Coal } \\
\text { Gas } \\
\text { Electric }\end{array}$ & $\begin{array}{l}0 \\
-0.47(0.29) \\
-0.19(0.24) \\
-0.39(0.27) \\
0.08(0.18)\end{array}$ & 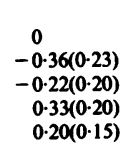 \\
\hline $\begin{array}{l}\text { Maternal age (yr) } \\
<25 \\
25-\end{array}$ & $\begin{array}{l}0 \\
-0.17(0 \cdot 16)\end{array}$ & $\begin{array}{l}0 \\
-0 \cdot 12(0 \cdot 13)\end{array}$ \\
\hline
\end{tabular}


the child's life, the associations being of similar magnitude. This gives some support to the finding by Said et $a^{1}$ of association between parental smoking and colic, though the effect in our subjects is somewhat diluted by the longer study period and the wider class of alimentary illness.

A mechanism for the association between colic and parental smoking is unclear, though it may be due to a link between taste, smell, and reflex intestinal activity. There is the possibility that the observed association may not be causal but may reflect the fact that parental, and particularly the mother's, smoking habit is associated with the child's social and demographic characteristics, or more probably aspects of their home environment such as quality of care given to the child. For example, mother's smoking might reflect inversely her maternal attitudes and personality and, as a result, the general level of health care provided to the child, including attention and mothering time. However the association with maternal smoking is found fairly consistently in our analysis, despite controlling for other factors. A further analysis in which a finer social class scale was used instead of type of heating resulted in similar estimated effects of smoking, showing that the effect of maternal smoking was resistant to controlling for other variables.

Maternal smoking, maternal education, family living standards, and quality of care provided to the child were included as potential confounding factors in a study in New Zealand ${ }^{7}$ primarily aimed at quantifying the effects of breast feeding on respiratory and gastrointestinal morbidity. These factors accounted for some of the crude difference in morbidity rates between breast and bottle fed infants for respiratory illness but not for gastrointestinal illness. The effect of feeding type in our study was fairly small, possibly because it reflected only feeding practice on discharge from hospital, whereas more detailed follow-up information could have given greater importance to this variable.

The evidence against smoking during and after pregnancy as it affects the health of the chid is now substantial. Maternal smoking is well known to be associated with low birthweight; it has been shown in a follow-up study to have substantial effects on pulmonary function; ${ }^{8}$ parental smoking is associated with frequency of cough and respiratory illness in offspring ${ }^{\mathrm{eg}, 9-11}$ and with growth after birth ${ }^{12} 13$ as well as the later uptake of the smoking habit. ${ }^{14} 15$ This new analysis confirms the finding of Said et al, ${ }^{1}$ implicating a further category of ill health associated with passive smoking. Each effect taken above may be small and within physiological limits but, when viewed together, they have an adverse influence on many aspects of child development.

This study was funded by grants from the Tayside Health Board and the Scottish Home and Health Department.

\section{References}

${ }^{1}$ Said G, Patois E, Lellouch J. Infantile colic and parental smoking. Br Med J 1984; 289: 660.

2 Walker CHM, et al. Tayside Infant Morbidity and Mortality Study. Final Report of the Working Group. Tayside Health Board, Vernonholme, Riverside Drive, Dundee 1985.

3 Baker RJ, Nelder JA. The GLIM System, Release 3. Oxford: Numerical Algorithms Group.

${ }^{4}$ Ogston SA, Florey C du V, Walker CHM. Tayside Infant Morbidity and Mortality Study: Effect on health of using gas for cooking. Br Med J 1985; 290: 957-60.

${ }^{5}$ Goldstein H. Design and analysis of longitudinal studies. London: Academic Press, 1979.

${ }^{6}$ Bishop YMM, Fienberg SE, Holland PW. Discrete multivariate analysis, Cambridge, Mass: MIT Press, 1975.

${ }^{7}$ Fergusson DM, Horwood J, Shannon FT, Taylor B. Breast feeding, gastro-intestinal and lower respiratory illness in the first 2 years. Aust Paed J 1981; 17: 191-5.

8 Taylor IB, Weiss ST, Munoz A, Rosner B, Speizer FE. Longitudinal study of the effects of maternal smoking on pulmonary function in children. New Engl J Med 1983; 309: 699-703.

${ }^{9}$ Leeder SR, Corkhill RT, Irwig LM, Holland WW, Colley JRT. Influence of family factors on the incidence of lower respiratory illness during the first year of life. $\mathrm{Br} J$ Prev Soc Med 1976; 30: 203-12.

${ }^{10}$ Charlton A. Children's coughs related to parental smoking. Br Med J 1984; 288: 1647-9.

${ }^{11}$ Chen Y, Lid W, Yu S. Influence of passive smoking on admissions for respiratory illness in early childhood. $\mathrm{Br}$ Med J 1986; 293: 303-6.

12 Berkey CS, Ware JH, Speizer FE, Ferris BG. Passive smoking and height growth of preadolescent children. Int J Epidemiol 1984; 13: 454-8.

${ }^{13}$ Rona RJ, Chin S, Florey C du V. Exposure to cigarette smoking and children's growth. Int J Epidemiol 1985; 14: 402-9.

${ }^{14}$ Bewley BR, Bland JM, Harris R. Factors associated with the starting of cigarette smoking by primary school children. Brit J Prev Soc Med 1974; 28: 37-44.

15 Alexander HM, Callcott R, Dobson AJ, Hardes GR, Lloyd DM, O'Connell DL, Leeder SR. Cigarette smoking and drug use in schoolchildren. IV-Factors associated with changes in smoking behaviour. Int $J$ Epidemiol 1983; 12: 59-66. 